\title{
Components of the covariances between reproductive performance traits and milk protein concentration and milk yield in dairy cows
}

\author{
J. M. Morton, ${ }^{* 1}$ J. E. Pryce, $† \ddagger$ and M. Haile-Mariam $†$ \\ *Jemora Pty Ltd., PO Box 2277, Geelong, Victoria 3220, Australia \\ †Agriculture Victoria, AgriBio, Centre for AgriBioscience, Bundoora, Victoria 3083, Australia \\ $\ddagger$ School of Applied Systems Biology, La Trobe University, Bundoora, Victoria 3083, Australia
}

\begin{abstract}
Reproductive performance in dairy cows can be improved through genetic selection and herd management. Milk protein concentration is strongly associated with various measures of reproductive performance, but the relative importance of genetic and environmental components of these associations have not been defined. The primary objective of this study was to estimate the magnitudes of correlations and covariances between 9 reproductive performance traits in dairy cows and each of milk protein concentration and milk yield at 4 levels: genetic, permanent environmental effects of cow, herd-year-season, and residual levels. A retrospective single cohort study was conducted using data collected from seasonally and split calving dairy herds. We used animal models to partition covariances for the relationships between 9 fertility traits and each of milk protein concentration and milk yield at lactation level, with up to 80,203 lactations from 27,244 cows that were 780 herd-year-seasons in 65 herds. For the fertility traits, of the explained covariance with milk protein concentration, between 33 and $79 \%$ (median 53\%) was genetic and 21 to $67 \%$ (median $47 \%$ ) was nongenetic. We concluded that research should be conducted to identify management strategies that capture the nongenetic components of relationships between milk protein concentration and reproductive performance. Genetic correlations with milk protein concentration were generally similar to genetic correlations with milk yield, but the correlation with milk protein concentration was closer (i.e., the absolute value of the correlation coefficient was nearer to 1) for pregnant by wk 6 , a key trait for seasonally and split calving dairy herds (correlation coefficient \pm standard error $=0.28 \pm 0.05$ and $-0.17 \pm 0.07$ for milk protein concentration and milk yield, respectively). As the associations also have
\end{abstract}

Received June 1, 2017.

Accepted January 31, 2018.

${ }^{1}$ Corresponding author: johnmorton.jemora@gmail.com substantial genetic components, it is possible that reliabilities of estimated breeding values for fertility may be improved by including milk protein concentration in multitrait genetic evaluation models for fertility traits. From our preliminary analyses, reliabilities were only slightly higher when pregnancy by wk 6 of the breeding period was analyzed with milk protein concentration rather than alone or with milk yield, but further research should be considered to assess this question. Importantly, the benefits of these strong relationships can only be fully harnessed through joint use of both management strategies and genetic strategies.

Key words: reproductive performance, seasonal milk production systems, genetic parameters

\section{INTRODUCTION}

Reproductive performance in dairy cows is important because delayed conception results in reduced annual milk yield (Auldist et al., 2007) and increased chance of culling (Rajala-Shultz and Grohn, 1999). Reproductive performance in dairy cows can be improved through genetic selection (Berry et al., 2014) and herd management changes. Milk protein concentration has been positively associated with reproductive performance in dairy cows phenotypically in numerous studies (e.g., Opsomer et al., 2000; Morton, 2004; Madouasse et al., 2010). This relationship has been attributed to energy balance during early lactation (Yang et al., 2009; Madouasse et al., 2010), but further research is required to allow the benefits of the association to be captured in dairy herd management. The current study is one of an ongoing series of studies with the ultimate aim of providing the necessary information to allow the benefits of the milk protein concentration-reproductive performance association to be captured (Fahey et al., 2008, 2017; Douglas et al., 2016; Morton et al., 2016a,b, 2017 ); the relationship is not due to confounding by milk yield, as positive associations are still present after adjusting for milk yield in multivariable regression models. Associations between milk protein concentra- 
tion and reproductive performance are weaker at higher early lactation milk yields, but positive associations are evident over a wide range of milk yields (Morton et al., 2016a). It is possible that both genetic and environmental factors affecting both milk protein concentration and reproductive performance contribute to these phenotypic associations. However, to our knowledge, the relationships between milk protein concentration and reproductive performance traits in dairy cows have not been separated into genetic and nongenetic components. A need exists to quantify the contributions of genetic effects, nongenetic cow effects, and herd effects to these relationships, as this would inform directions for future research. As indicator variables can improve the reliability of breeding values for fertility, if the relationships are predominantly genetic and explain a reasonable proportion of genetic variation in fertility traits, extending multitrait models for fertility genetic evaluation to include milk protein concentration should be considered. In contrast, if the relationships are predominantly nongenetic, research should focus on management changes that capture the nongenetic effects on reproductive performance.

The possibility of increasing the reliability of breeding values for fertility traits by using milk protein concentration is worth exploring. To our knowledge, milk protein concentration has not been used in this way in any country, but in some countries the effects of including milk yield in multitrait genetic evaluation models have been assessed (e.g., Olori et al., 2002; Harris et al., 2005; Sun et al., 2010). Accordingly, for comparison purposes, the covariance components between milk yield and reproductive performance were also of interest.

In Australia, where seasonally and split calving systems are the predominant calving systems, an important reproductive performance trait is whether the cow became pregnant in the first 6 wk of the breeding period (Morton, 2004). To derive this measure, pregnancy test data that allow accurate determination of conception dates over the whole breeding period are required. For accurate estimates of conception dates, pregnancy testing must be timed such that pregnant cows are examined relatively early in their pregnancy (Matthews and Morton, 2012; Brownlie et al., 2016). Availability of these high-quality data is currently limited (e.g., González-Recio et al., 2016); as a result, genetic evaluation of fertility in Australia currently relies on a multitrait model that uses calving interval, calving to first service interval, occurrence of pregnancy at any time in the breeding period, nonreturn to service, and lactation length. Results from this multitrait model are used to generate a fertility breeding value based on calving interval transformed into pregnancy by wk 6 .
This model was designed to capture as much of the genetic variation in fertility as possible using traits that were commonly available. Therefore, in addition to using the data on pregnancy by wk 6 to separate the relationship between milk protein concentration and fertility traits into different components, correlations between pregnancy by wk 6 and other fertility traits including some commonly available traits currently included in the multitrait model were of interest to assess how closely related they are with pregnancy by wk 6 .

The primary objective of our study was to estimate the magnitudes of correlations and covariances for the relationships between 9 reproductive performance traits in dairy cows and each of milk protein concentration and milk yield at 4 levels: genetic, permanent environmental effects of cow, herd-year-season, and residual levels. We also estimated genetic and other correlations between a reproductive performance trait of primary interest in seasonally and split calving dairy herds, namely whether the cow become pregnant in the first 6 wk of the breeding period, and 8 other reproductive traits at these levels. We also performed preliminary analyses to quantify the advantage of analyzing milk protein concentration with pregnancy by wk 6 on the reliabilities of estimated breeding values of sires compared with the reliabilities when analyzing with milk yield and with neither.

\section{MATERIALS AND METHODS}

\section{Study Overview}

A retrospective single cohort study was conducted using data collected from 74 seasonally and split calving dairy herds. We assessed covariances for the relationships between 9 fertility traits and each of milk protein concentration and milk yield at lactation level. Full details of herd, lactation, and breeding period selection reproductive performance measures, as well as measurement of milk yields and milk protein and fat concentrations are provided in Morton et al. (2016b).

\section{Herd Selection}

In 2010, 58 commercial dairy herds with early rectal ultrasound or manual pregnancy diagnoses were selected from clients of each of 4 veterinary practices in Victoria and Tasmania, Australia. These herds were selected because their data had been entered into a database, those data were considered by the herd's veterinary practitioners to be relatively complete and accurate (based on their knowledge of the herd staff data-recording practices and frequency of discrepancies and missing data), and, in 2009, all cows were preg- 
nancy tested within 17 wk after breeding period start date and those not diagnosed pregnant were retested after the end of the breeding period. In addition, all herd-years with sufficient pregnancy test data in the Australian Dairy Herd Improvement Scheme (ADHIS; now DataGene, https://datagene.com.au) national database were identified. Of these, 20 herds had early pregnancy test data $(\geq 80 \%$ of cows had at least 1 pregnancy diagnosis and $\geq 80 \%$ of all pregnancy diagnoses had either an estimated fetal age $\leq 17$ wk or a nonpregnant diagnosis) for at least 5 of the $6 \mathrm{yr}$ from 2004 to 2009, inclusive; all were selected and their data obtained from ADHIS. Four of these 20 herds were also represented in the 58 herds that were clients of the 4 veterinary practices; so 16 of these 20 herds were retained, giving a total of 74 distinct herds enrolled. One of these herds was subsequently excluded as substantial numbers of cows and calvings in that herd had not been entered into the database.

Breeding period start dates were determined within each herd based on daily numbers of services (i.e., AI and any recorded bull services). Dates when bulls were removed from the lactating herds and bull services were generally not recorded. End dates for breeding periods were defined based on conception dates derived from pregnancy testing. Herds could have multiple breeding periods commencing in the same calendar year; this occurred when the herd was split calving.

\section{Selection of Lactations}

Lactations commencing on or between $120 \mathrm{~d}$ before and $30 \mathrm{~d}$ after their nearest breeding period start date were allocated to that breeding period. Breeding periods were considered to have adequate data for analyses only if they had more than 50 associated lactations and, for more than $80 \%$ of those lactations, the cow had at least 1 pregnancy diagnosis; otherwise, all lactations allocated to the breeding period were excluded. Lactations where the cow's date of birth was not recorded or where the cow was not recorded as being Holstein were excluded. Lactations with services or conception dates before the breeding period start date were also excluded, as were lactations where the cow was recorded as having been culled before the start of the breeding period. Lactations were also excluded where the identification code for the cow was invalid and where the cow's sire's identification code was not available or invalid.

\section{Fertility Traits}

Conception dates were determined from results of rectal ultrasound or manual pregnancy diagnoses and a total of 9 lactation-level reproductive performance measures were used as fertility traits (Table 1). For full details describing eligibility of lactations and calculations of these measures, see Morton et al. (2016b).

Table 1. Definition of fertility traits and criteria/methods for calculation

\begin{tabular}{|c|c|}
\hline Measure & Description of event (for binary traits) or variable and criteria for calculation \\
\hline $\begin{array}{l}\text { Submitted by wk } 3 \text { of the } \\
\text { breeding period }\end{array}$ & $\begin{array}{l}\text { Cow was inseminated or served at least once between breeding period start date }(\mathrm{d} 1) \text { and } \mathrm{d} 21 \text { (the end of } \\
\text { wk } 3 \text { ) of the breeding period }\end{array}$ \\
\hline $\begin{array}{l}\text { Pregnant by wk } 6 \text { of the } \\
\text { breeding period }\end{array}$ & $\begin{array}{l}\text { Cow was diagnosed as having conceived on or between breeding period start date (d 1) and d } 42 \text { (the end } \\
\text { of wk } 6 \text { ) of the breeding period }{ }^{1}\end{array}$ \\
\hline $\begin{array}{l}\text { Not pregnant by wk } 12 \text { of } \\
\text { the breeding period }\end{array}$ & $\begin{array}{l}\text { Cow did not conceive on or between breeding period start date (d 1) and d } 84 \text { (the end of wk 12) of the } \\
\text { breeding period }\end{array}$ \\
\hline $\begin{array}{l}\text { Not pregnant by the end } \\
\text { of the breeding period }\end{array}$ & Cow did not conceive on or between breeding period start date $(\mathrm{d} 1)$ and the end of the breeding period ${ }^{1}$ \\
\hline \multicolumn{2}{|l|}{ Continuous data trait } \\
\hline $\begin{array}{l}\text { Calving to first service } \\
\text { interval }\end{array}$ & $\begin{array}{l}\text { Interval from study calving }{ }^{2} \text { to first AI; intervals for cows with no recorded AI were ended } 1 \mathrm{~d} \text { after the last } \\
\text { possible date that the cow could have been inseminated }\end{array}$ \\
\hline $\begin{array}{l}\text { Calving to conception } \\
\text { interval }\end{array}$ & $\begin{array}{l}\text { Interval from study calving }{ }^{2} \text { to conception date; intervals for cows that did not conceive were ended } 1 \mathrm{~d} \\
\text { after the last possible date that conception could have occurred }\end{array}$ \\
\hline \multirow{2}{*}{\multicolumn{2}{|c|}{$\begin{array}{l}{ }^{1} \text { For each of conceived to first service; pregnant by wk } 6 \text {; and not pregnant by wk } 12,21 \text {, and end of the breeding period, lactations were only } \\
\text { included where the cow was either diagnosed pregnant or was pregnancy tested with negative results, respectively, at least } 28 \mathrm{~d} \text { after their first } \\
\text { service date; } \mathrm{d} 42,84 \text {, and } 147 \text { of the breeding period; and the end of breeding period date. }\end{array}$}} \\
\hline & \\
\hline \multicolumn{2}{|c|}{${ }^{2}$ Study calvings were the calvings at the commencement of the lactations selected for the study. } \\
\hline \multicolumn{2}{|c|}{${ }^{3}$ One day after the earliest of (1) the cow's cull date and (2) the end of breeding period date. } \\
\hline
\end{tabular}




\section{Milk Yields and Milk Protein Concentrations}

Milk protein concentrations and milk yield data were recorded as the part of the milk recording scheme operated by the milk-recording organization of each herd. Milk protein concentrations were calculated for the first $120 \mathrm{~d}$ of each lactation using 24-h milk recording data as 120-d protein yield divided by $120-\mathrm{d}$ milk yield. These 120-d yields were calculated, respectively, as areas under the lactation curves of 24-h protein yield and milk yield by time from calving. Lactation curves were defined assuming constant 24 -h yields from calving to first milk recording and linear interpolation between milk recordings. All milk production data were disregarded for lactations where 120-d milk protein concentration was $7 \%$ or higher. This resulted in exclusion of $0.1 \%$ (72) of the 63,109 lactations where milk recording data were available before exclusions due to invalid and missing cow and sire identity codes.

\section{Statistical Methods}

Fertility traits were analyzed in a series of 3-trait animal models to estimate their correlations with each of 120-d milk protein concentration and 120-d milk yield using pedigree details for cows obtained from the ADHIS national database. Herd-year-season was defined for each lactation using the calving date that commenced the lactation; calendar years were used, and January to June and from July to December were classified, respectively, as seasons 1 and 2. Each herd's region and source of data were categorized based on the combination of the geographic region in which the herd was located and the data source (veterinary practice or ADHIS). Cow age at calving, month of calving, region, and source of data were fitted as fixed effects for all traits. Interval from calving to the start of the breeding period was also fitted as a fixed effect when analyzing each fertility trait other than for conceived to first service, where interval from calving to first service were fitted as a fixed effect. Duration of the breeding period was also fitted as a fixed effect when analyzing not pregnant by the end of the breeding period. These intervals and duration of the breeding period are all strong determinants of the respective fertility traits in seasonally and split calving systems (Morton, 2004). As the primary objective of our study was to separate the covariance between fertility traits and milk protein concentration into 4 components (genetic, permanent environmental, herd-year-season, and residual components), the random effect of animal with additive genetic effects, the permanent environmental effect of cow (to account for repeated lactations by the same cow), and the effect of herd-year-season of calving were fitted. Before statistical analyses, calving intervals longer than $551 \mathrm{~d}$ were reset to $551 \mathrm{~d}$ to reduce the influence of long intervals on variance estimates (Haile-Mariam et al., 2013). All data analyses were carried out using ASReml (Gilmour et al., 2009).

The model in matrix notation can be represented as

$$
\mathbf{y}_{\mathrm{T}}=\mathbf{X}_{\mathrm{T}} \mathbf{b}_{\mathrm{T}}+\mathbf{Z}_{\mathrm{T}} \mathbf{a}_{\mathrm{T}}+\mathbf{W}_{\mathrm{T}} \mathbf{p}_{\mathrm{T}}+\mathbf{H}_{\mathrm{T}} \mathbf{h}_{\mathrm{T}}+\mathbf{e}_{\mathbf{T}}, \quad[1]
$$

where $\mathrm{y}_{\mathrm{T}}$ is the observation on 3 traits ( $\mathrm{T}$ is trait 1 to 3 ; i.e., pregnant by wk 6 , another fertility trait, and either 120-d milk protein concentration or milk yield), $\mathbf{X}_{\mathbf{T}}$ is the incidence matrix for fixed effects, $\mathbf{b}_{\mathbf{T}}$ is the vector of fixed effects, $\mathbf{Z}_{\mathrm{T}}$ is the incidence matrix for random effects of animal, $\mathbf{a}_{\mathbf{T}}$ is the vector of random animal genetic effects, $\mathbf{W}_{\mathbf{T}}$ is the incidence matrix for random permanent environmental effects of cow, $\mathbf{p}_{\mathbf{T}}$ is the vector of permanent environmental effects of cow, $\mathbf{H}_{\mathrm{T}}$ is the incidence matrix for random herd-year-season effects, $\mathbf{h}_{\mathbf{T}}$ is the vector of herd-year-season effects, and $\mathbf{e}_{\mathrm{T}}$ is the vector of random residual effects.

The expectations were $\mathrm{E}\left(\mathbf{y}_{\mathrm{T}}\right)=\mathbf{X}_{\mathrm{T}} \mathbf{b}_{\mathrm{T}}, \mathrm{E}\left(\mathbf{a}_{\mathbf{T}}\right)=0$, $\mathrm{E}\left(\mathbf{p}_{\mathbf{T}}\right)=0, \mathrm{E}\left(\mathbf{h}_{\mathbf{T}}\right)=0$, and $\mathrm{E}\left(\mathbf{e}_{\mathbf{T}}\right)=0$ with the following variance-covariance matrix:

$$
\begin{gathered}
\operatorname{Var}\left(\mathbf{a}_{\mathbf{T}}\right)=\mathbf{G} \otimes \mathbf{A}_{\mathbf{a}}, \operatorname{Var}\left(\mathbf{p}_{\mathbf{T}}\right)=\mathbf{P} \otimes \mathbf{I}_{\mathbf{c}}, \operatorname{Var}\left(\mathbf{h}_{\mathbf{T}}\right)= \\
\mathbf{H} \otimes \mathbf{I}_{\mathbf{h}}, \text { and } \operatorname{Var}(\mathbf{e})=\mathbf{R} \otimes \mathbf{I}_{\mathbf{e}},
\end{gathered}
$$

where $\mathbf{G}, \mathbf{P}, \mathbf{H}$, and $\mathbf{R}$ are variance-covariance matrices of size 9 (3 by 3 ) each; $\mathbf{A}_{\mathbf{a}}$ is the matrix of the additive genetic relationship among animals, $\mathbf{I}_{\mathrm{c}}$ is the identity matrix of permanent environmental effects of cows and $\mathbf{I}_{\mathrm{h}}$ is the identity matrix of herd-year-season effects, $\mathbf{I}_{\mathrm{e}}$ is the identity of each record, and $\otimes$ is the Kronecker matrix product. The $\mathbf{A}_{\mathrm{a}}$ matrix was constructed using all the available pedigree information on all animals, which was traced back to the 1950s. Animals with unknown parents were grouped based on their birth year, country of origin, and sex according to standard ADHIS/DataGene genetic evaluation procedures (ADHIS, 2004).

Proportions of estimated covariances at the various levels for associations between each fertility trait and each of milk protein concentration and milk yield were calculated. For calving interval, the herd-year-season covariances were positive whereas all other covariances were negative; thus, proportions of estimated covariances were not calculated.

The reliabilities of estimated breeding values for pregnant by wk 6 for bulls with different numbers of daughter-lactations were calculated when estimated 
breeding values were obtained from a single-trait model, and jointly analyzed with either milk protein concentration or milk yield. Reliabilities were calculated for each sire as 1 - (prediction error variance/genetic variance).

\section{RESULTS}

\section{Numbers of Herds and Lactations}

For the traits with data for most lactations (intervals from calving to each of first service and conception), the 80,203 lactations were from 27,244 cows from 780 herd-year-seasons from 65 herds (Table 2). For these lactations, the distribution of ages at calving was $22 \%$ or 17,529 for $2 \mathrm{yr} ; 19 \%$ or 14,942 for $3 \mathrm{yr} ; 16 \%$ or 13,016 for $4 \mathrm{yr} ; 31 \%$ or 24,811 for 5 to $7 \mathrm{yr}$; and $12 \%$ or 9,905 for 8 yr or older.

\section{Reproductive Performance}

The means and standard deviations of the traits considered in this study for all lactations pooled are shown in Table 2. For $47 \%$ of lactations, the cow became pregnant by wk 6 , and for 32,22 , and $21 \%$ of lactations the cow did not become pregnant by wk 12, 21, and the end of the breeding period, respectively. For $66 \%$ of lactations the cow was submitted by wk 3 , and for $38 \%$ of lactations the cow conceived to first service. Of the 80,203 lactations with calving to first service intervals allocated, for $12 \%$ the cow had no recorded AI; thus, intervals were ended $1 \mathrm{~d}$ after the last possible date that the cow could have been inseminated. The mean and standard deviation for these latter intervals were 157.5 and 55.6 d, respectively. Of the 80,203 lactations with calving to conception intervals allocated, for $23 \%$ the cow had no recorded conception date; thus, their intervals were ended $1 \mathrm{~d}$ after the last possible date that the cow could have conceived or been diagnosed pregnant (for cows whose final pregnancy diagnosis was before or soon after the end of the breeding period). The mean and standard deviation for these latter intervals were 160.5 and $51.4 \mathrm{~d}$, respectively. Distributions of calving to first service intervals and calving to conception intervals are shown in Figure 1. Distributions of calving to first service and calving to conception intervals were both right-skewed but close to normal distributions, supporting the decision to analyze these data using linear models. Of the 51,672 lactations with calving intervals of at least $290 \mathrm{~d}, 11 \%(5,523)$ were longer than $551 \mathrm{~d}$ and were reset to $551 \mathrm{~d}$ to reduce the influence of long intervals on variance estimates. The distribution of calving intervals was approximately normally distributed other than the small secondary peak at $551 \mathrm{~d}$.

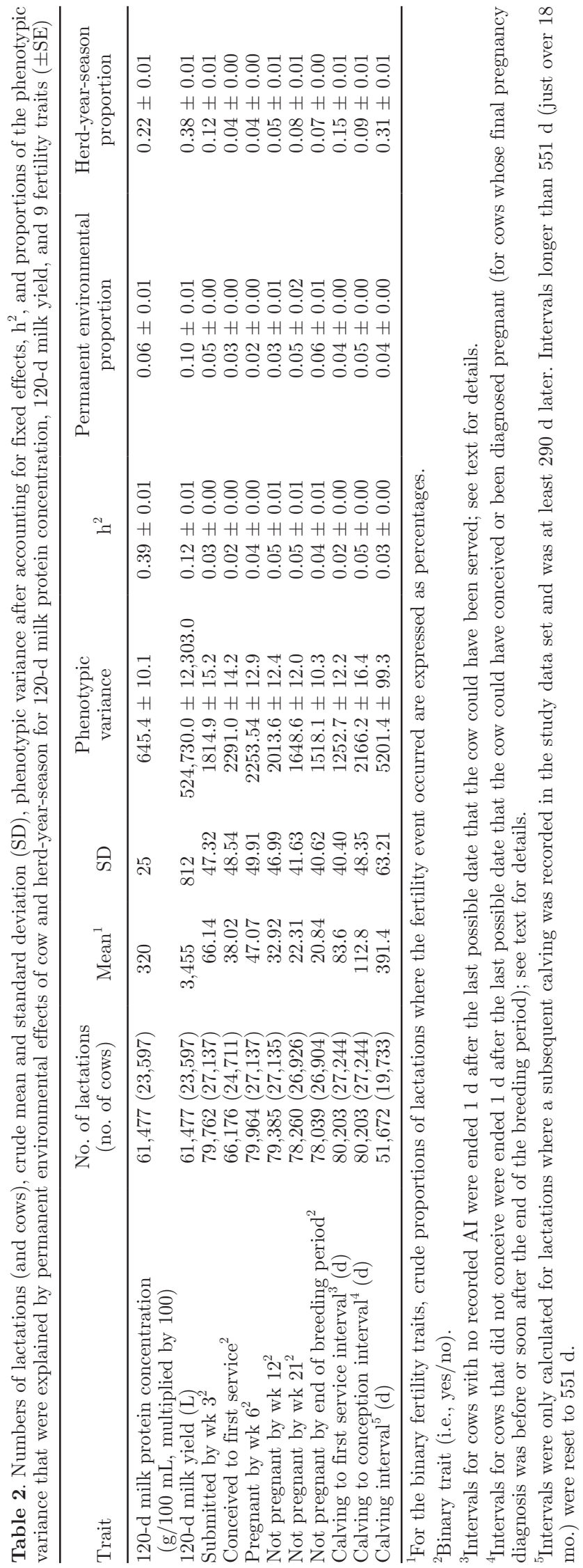

Journal of Dairy Science Vol. 101 No. 6, 2018 


\section{Heritability and Variance Explained by Different Components}

Phenotypic variances, heritability, and proportions of the phenotypic variance that were explained by the permanent environmental effects of cow and herd-yearseason for 120-d milk protein concentration, 120-d milk yield, and 9 fertility traits are shown in Table 2 . Based on heritabilities, the traits fell into 3 groups; the highest heritability was for milk protein concentration (estimate $\pm \mathrm{SE} ; 0.39 \pm 0.01$ ), whereas milk yield was intermediate $(0.12 \pm 0.01)$ and the fertility traits all had low heritability (0.02 to 0.05 ), with the lowest for calving to first service interval and conceived to first service $(0.02 \pm 0.00$ for both $)$. The permanent environmental effect of cow as a proportion of the phenotypic variance (i.e., the proportion of variance explained by repeated records of cows) was highest for milk yield and lowest for pregnant by wk 6 . Of the total variance explained by the random effects, herd-year-season variance was the largest for all traits except for pregnant by wk 6 . Herd-year-season explained more than $10 \%$ of the total variance for 120-d milk yield, calving interval, 120-d milk protein concentration, calving to first service interval, and submitted by wk 3 .

\section{Correlations Between Fertility and Indicator Traits due to Different Components}

Coefficients for correlations between the 9 fertility traits and each of 120-d milk protein concentration and 120-d milk yield are shown in Table 3. Genetic correlations with milk protein concentration were in the opposite direction to those for milk yield. For milk protein concentration, genetic correlations were positive for desirable traits and negative for undesirable traits, showing that high milk protein concentration is associated genetically with better fertility. In contrast, for milk yield, genetic correlations were negative for desirable traits and positive for undesirable traits, showing that high milk yield is associated genetically with worse fertility. Absolute values of genetic correlation coefficients with milk protein concentration ranged from 0.16 \pm 0.05 to $0.32 \pm 0.06( \pm \mathrm{SE})$ and $0.15 \pm 0.06$ to $0.27 \pm$ 0.06 for milk yield. Coefficients for the genetic correlations with milk protein concentration were generally similar to correlations with milk yield. The largest difference between absolute genetic correlation coefficients was for pregnant by wk $6(0.28 \pm 0.05$ with milk protein concentration vs. $0.17 \pm 0.07$ with milk yield). Within the permanent environmental effects of cow, absolute
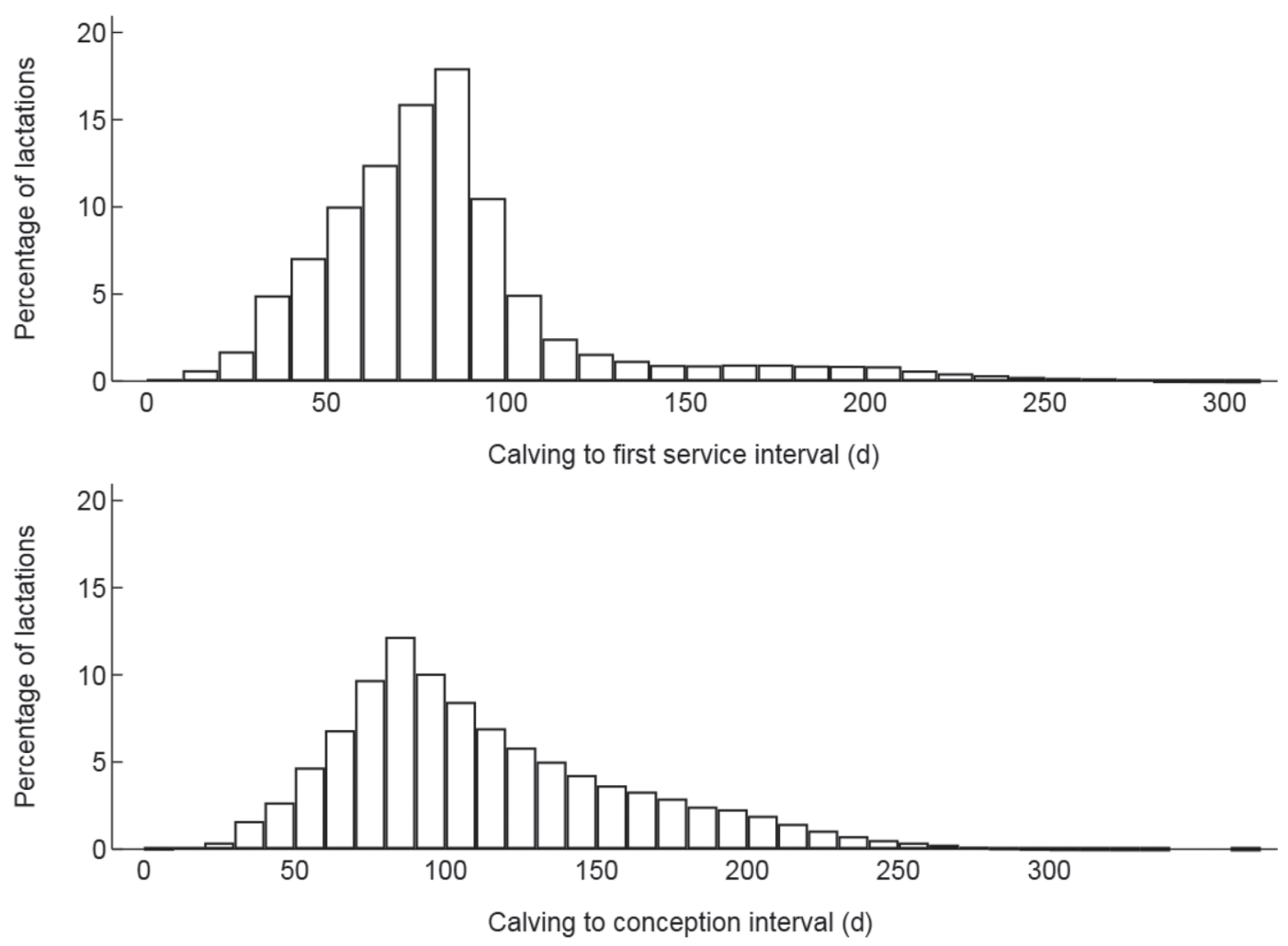

Figure 1. Distributions of calving to first service intervals and calving to conception intervals in study lactations. Intervals for cows with no recorded AI and for cows that did not conceive were ended $1 \mathrm{~d}$ after the last possible date that the cow could have been inseminated and conceived, respectively; these intervals are included in the distributions. 
correlations between 3 fertility traits (not pregnant by wk 21, not pregnant by end of breeding period, and calving interval) and milk protein concentration were markedly closer to unity than with milk yield. Residual correlations between the various fertility traits and both milk protein concentration and milk yield were closer to zero than the genetic correlations.

For comparison, we also assessed correlations between each of fat-to-protein ratio, milk fat concentration, and pregnant by wk 6 . At the level of permanent environmental effect of cow, the correlation coefficient for fat-to-protein ratio was moderately high $(-0.55)$, but the correlations at the other 3 levels were virtually zero. Milk fat concentration was not closely associated with fertility traits at any level.

\section{Covariance Explained by the Different Components}

Results of partitioning of covariances with milk protein concentration are shown for fertility traits in Table 4. Covariances at genetic, permanent environmental, herd-year-season, and residual levels were all positive for desirable fertility traits and all negative for undesirable fertility traits, other than for calving interval where the herd-year-season covariance was positive. Accordingly, proportions of estimated covariances were not calculated for calving interval. For the remaining 8 fertility traits, between 55 and $87 \%($ median $=74 \%)$ of the total covariance with milk protein concentration was explained collectively by the sum of covariances at genetic, permanent environmental effect of cow, and herd-year-season levels. Of the explained covariances, between 33 and $79 \%$ (median 53\%) was genetic. The highest percentages were for conceived to first service (79\%) and pregnant by wk 6 and calving to conception interval (both 64\%). The lowest genetic percentages were for not pregnant by wk $21(33 \%)$ and not pregnant by the end of the breeding period $(38 \%)$. Of the remaining explained covariance (i.e., the nongenetic explained covariance), $11 \%$ was at herd-year-season level (rather than permanent environmental level) for conceived to first service. In contrast, 41 and $52 \%$ was at herd-year-season level for not pregnant by the end of the breeding period and by wk 21, respectively, and between 60 and $93 \%$ was at herd-year-season level for the other fertility traits.

In contrast to milk protein concentration, covariances with milk yield at genetic levels were all negative for desirable fertility traits and all positive for undesirable fertility traits, whereas covariances at permanent environmental, herd-year-season, and residual levels were variously positive and negative. For example, for pregnant by wk 6 , covariances with milk yield at genetic, permanent environmental, herd-year-season, and

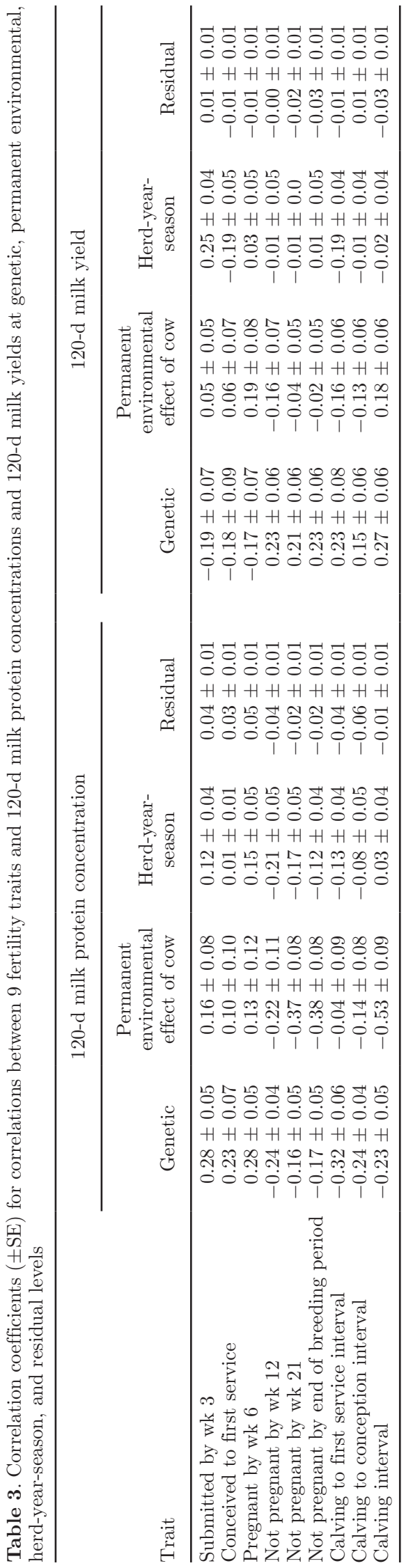

Journal of Dairy Science Vol. 101 No. 6, 2018 


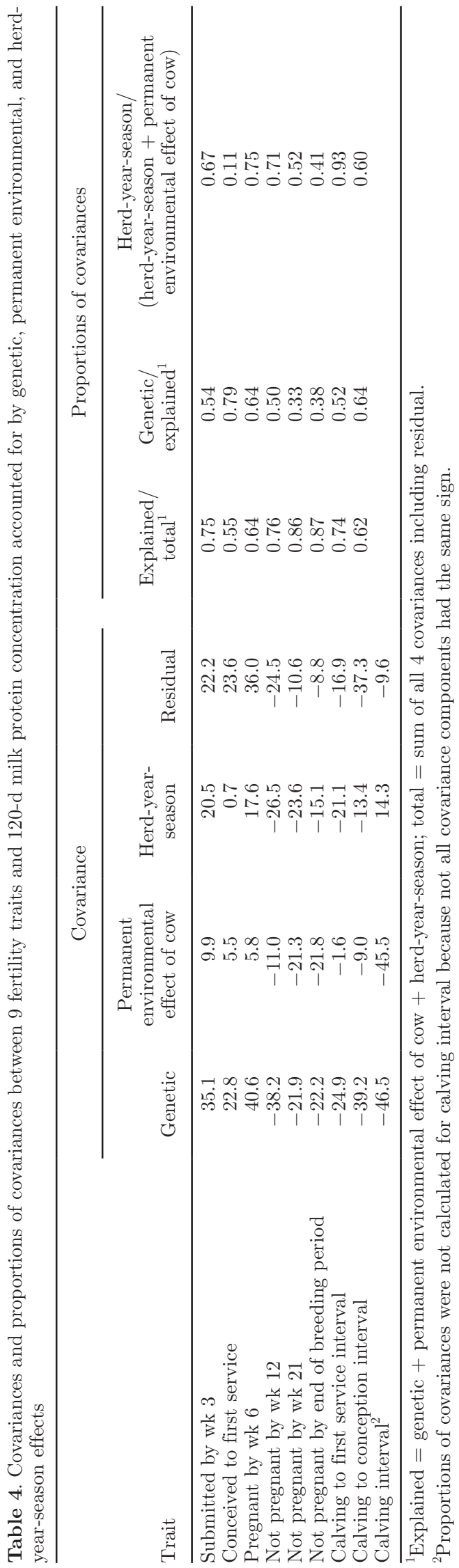

residual levels were, respectively, $-385.2,113.6,311.7$, and -264.7 . Disregarding signs of covariances, for milk protein concentration, the genetic covariances were between 1.0 and 15.3 (median 3.5) times larger than permanent environmental covariances and for milk yield, and genetic covariances were between 1.1 and 8.7 (median 2.0) times larger than permanent environmental covariances.

\section{Correlations Between Pregnant by wk 6 and Other Reproductive Performance Traits}

Correlations between pregnant by wk 6 (a key trait in seasonally and split calving dairy herds) and each of the other 8 reproductive traits are reported in Table 5 . Genetic correlations $( \pm \mathrm{SE})$ with submitted by wk 3 and calving to first service interval were weakest $(0.67 \pm 0.06$ and $-0.61 \pm 0.06$, respectively), confirming that pregnant by wk 6 is influenced by additional aspects of fertility over and above the time for the cow to commence cycling after calving and the strength of her estrus signs. Genetic correlations with the other 6 traits were high (absolute values $=0.96$ to $0.98 ; \mathrm{SE}=$ 0.01 to 0.02 ). Calving to conception interval was closely correlated with pregnant by wk 6 at all levels, and the phenotypic correlation coefficient was $-0.74 \pm 0.00$, indicating that it can be a useful measure of fertility at the phenotypic level when interval from calving to breeding period start date is accounted for. On the other hand, at the phenotypic level, calving interval and pregnant by wk 6 were less closely correlated, indicating that calving interval is not a useful phenotypic measure of reproductive performance in seasonally and split calving herds where a primary trait of interest is pregnant by wk 6 . The permanent environmental-level correlation between pregnant by wk 6 and calving to first service interval was much weaker or reversed (i.e., positive) relative to the correlations at the genetic, herd-year-season, and residual levels (all of which were negative).

\section{Effects of Including Milk Protein Concentration on the Reliability of Breeding Value for Pregnant by wk 6}

Reliabilities of sires' estimated breeding values for pregnant by wk 6 when analyzed alone, with milk protein concentration, or with milk yield were tabulated (Table 6 ) by the number of daughter-lactations for the sire. For sires with at least 100 daughter-lactations, reliabilities were quite high and were only minimally increased when pregnant by wk 6 was analyzed with milk protein concentration rather than alone. Slightly larger increases were evident for sires with less than 100 
Table 5. Correlation coefficients $( \pm \mathrm{SE})$ for correlations between various fertility traits and pregnant by wk 6 of the breeding period (an important trait in seasonally and split calving herds) at genetic, permanent environmental, herd-year-season, and residual levels, and phenotypic correlations

\begin{tabular}{|c|c|c|c|c|c|}
\hline Trait & Genetic & $\begin{array}{l}\text { Permanent } \\
\text { environmental } \\
\text { effect of cow }\end{array}$ & $\begin{array}{l}\text { Herd-year- } \\
\text { season }\end{array}$ & Residual & Phenotypic \\
\hline Submitted by wk 3 & $0.67 \pm 0.06$ & $0.28 \pm 0.11$ & $0.43 \pm 0.04$ & $0.22 \pm 0.0$ & $0.25 \pm 0.00$ \\
\hline Not pregnant by wk 12 & $-0.98 \pm 0.01$ & $-0.85 \pm 0.06$ & $-0.80 \pm 0.02$ & $-0.60 \pm 0.0$ & $-0.63 \pm 0.00$ \\
\hline Not pregnant by wk 21 & $-0.96 \pm 0.02$ & $-0.81 \pm 0.06$ & $-0.58 \pm 0.03$ & $-0.45 \pm 0.0$ & $-0.49 \pm 0.00$ \\
\hline Not pregnant by end of breeding period & $-0.96 \pm 0.02$ & $-0.84 \pm 0.06$ & $-0.52 \pm 0.04$ & $-0.44 \pm 0.0$ & $-0.48 \pm 0.00$ \\
\hline
\end{tabular}

daughter-lactations when pregnant by wk 6 was analyzed with milk protein concentration. However, even then, reliabilities were much less than for sires with at least 100 daughter-lactations. Reliability increases were negligible when pregnant by wk 6 was analyzed with milk volume rather than alone.

\section{DISCUSSION}

The most important finding from our study was that, of the explained covariances between milk protein concentration and fertility traits, between 33 and $79 \%$ $($ median $=53 \%)$ was genetic and 21 to $67 \%$ (median $=$ $47 \%$ ) was nongenetic. Thus, these results show that substantial proportions of explained covariances are nongenetic. Importantly, our results also show substantial genetic components to the associations between 120-d milk protein concentration and these fertility traits in lactating dairy cows. Thus, the benefits of these strong relationships for improving dairy cow reproductive performance can only be fully harnessed through both nongenetic and genetic management strategies.

Further research is warranted to assess the potential use of genetic components of the associations to improve reliability of breeding value estimates. Our results do not indicate that large increases in reliabilities would occur by including milk protein concentration in multitrait genetic evaluation models for fertility traits. However, as our analyses are preliminary, as milk protein concentration data are already routinely collected in most countries, and as further more refined analyses could be relatively inexpensive, we concluded that further research should be considered to assess this question. Based on our results, milk protein concentration may be a little more effective than milk yield if the main fertility trait for genetic evaluation is pregnant by wk 6 ; pregnant by wk 6 was a little more closely correlated genetically with milk protein concentration ( $\mathrm{r} \pm$ $\mathrm{SE} ; 0.28 \pm 0.05)$ than with milk yield $(0.17 \pm 0.07)$. In a New Zealand study, Harris and Pryce (2004) reported lower genetic correlations between milk protein concentration and each of submitted by wk 3 and giving birth to a calf sired by AI, a trait roughly similar to pregnant by wk $6(0.18 \pm 0.05$ and $0.20 \pm 0.09$, respectively $)$ compared with $0.28 \pm 0.05$ for each of submitted by wk 3 and pregnant by wk 6 in the current study. However, those authors used milk protein concentration for the first $270 \mathrm{~d}$ of lactation, and it is possible that genetic correlations are closer if early lactation milk protein concentration is used, as is the case with calving interval (Haile-Mariam et al., 2003a). In that study, reliabilities of sire EBV for calving interval were higher when milk yield was used as a predictor rather than milk protein concentration assessed in early and late lactation.

Table 6. Average reliabilities of sires' EBV for pregnant by wk 6 when analyzed alone, with milk protein concentration, or with milk yield by number of daughter-lactations for the sire

\begin{tabular}{lrccc}
\hline & & \multicolumn{3}{c}{ Trait combination } \\
\cline { 3 - 5 } $\begin{array}{l}\text { Number of daughter- } \\
\text { lactations for the sire }\end{array}$ & $\begin{array}{c}\text { No. of } \\
\text { sires }\end{array}$ & $\begin{array}{c}\text { Pregnant by } \\
\text { wk 6 alone }\end{array}$ & $\begin{array}{c}\text { With milk protein } \\
\text { concentration }\end{array}$ & $\begin{array}{c}\text { With milk } \\
\text { yield }\end{array}$ \\
\hline$>100$ & 136 & 0.684 & 0.699 & 0.687 \\
$\geq 50$ to 100 & 88 & 0.450 & 0.474 & 0.456 \\
$\geq 25$ to 49 & 199 & 0.306 & 0.332 & 0.313 \\
$\geq 10$ to 24 & 587 & 0.227 & 0.249 & 0.232 \\
$\geq 5$ to 9 & 514 & 0.153 & 0.142 & 0.123 \\
All sires & 2,251 & 0.119 & & \\
\hline
\end{tabular}


However, in seasonally and split calving dairy herds, calving interval is not closely phenotypically related to pregnant by wk 6 of the breeding period, and research is required to assess the effects of including milk protein concentration in a multitrait model where the breeding objective is pregnant by wk 6 . From our preliminary analyses, for sires with at least 100 daughter-lactations reliabilities were quite high and were only minimally increased when pregnant by wk 6 was analyzed with milk protein concentration rather than alone. Slightly larger increases were evident for sires with less than 100 daughter-lactations when pregnant by wk 6 was analyzed with milk protein concentration. For these analyses, all lactations had high-quality reproductive data and it would be of particular interest to also assess the effects of including milk protein concentration on reliability when fertility data are unavailable for many lactations. In Australia, for herds that participate in milk recording, only about 60 to $75 \%$ of cows have any fertility information in the national database, whereas milk protein concentration data are available for almost $90 \%$ of cows. Collecting fertility data on all cows can be the most effective way of increasing reliabilities. However, this has been difficult to achieve in Australia, whereas milk protein concentration data are already available for most cows that participate in milk recording, so including milk protein concentration could be implemented relatively easily and cheaply. Increasing the reliability of breeding value estimates for sires with very few daughters with any fertility data is important for the Australian dairy industry. Further research should also consider including all fertility traits simultaneously and then including milk protein concentration and milk yield.

Our results also provide information about the choice of variables for inclusion in multitrait models to estimate fertility breeding values. Genetic correlations between pregnant by wk 6 and measures based on first service (submitted by wk 3 and calving to first service) were low, so breeding values for female fertility should not be based solely on these latter traits. Both of these fertility measures are useful, however, because they are partial indicators of the cow's ability to commence cycling soon after calving and to display strong estrus signs; thus, they should be included in multitrait fertility evaluations. Although calving interval is not directly related to pregnancy by wk 6 , our results show that it is genetically closely correlated with pregnant by wk 6 , despite the fact that we truncated long intervals at $551 \mathrm{~d}$ and disregarded lactations with no recorded recalving.

When analyzing data on economic traits in Australia (e.g., Haile-Mariam et al. 2003b, 2013; González-Recio et al., 2016) and other countries (Harris et al., 2005), herd-year-season is usually fitted as a fixed effect. However, in the current study, as our objective was to partition covariance components between fertility traits and milk protein concentration or yield, herdyear-season was fitted as a random effect. This allowed us to quantify the proportions of variance and covariance due to herd-year-season effect. Our results show that important proportions of explained covariances are nongenetic, and the partitioning of covariances can help focus research and extension aiming to capture the benefits of the milk protein concentration-reproductive performance association through nongenetic strategies. We have shown that a large proportion of the variance in some fertility traits is at herd-year-season level. Of the explained covariance that was nongenetic, little was at herd-year-season level for conceived to first service. In contrast, 40 to $50 \%$ was at herd-yearseason level for not pregnant by wk 21 and by the end of the breeding period, and between 60 and $93 \%$ was at herd-year-season level for the other fertility traits. These observations agree with the large differences in reproductive performance observed between breeding periods among study herds (Morton, 2011). For example, for 568 breeding periods from the 74 herds in that study, the lowest and highest percentages of cows that became pregnant by wk 6 of the breeding period were 12 and $82 \%$, respectively. Causal mechanisms for the association between milk protein concentration and reproductive performance are likely to relate, in part, to management strategies that are applied to the whole herd. For example, nutritional management may affect both fertility and milk protein concentration and may partly explain some of the herd-year-season covariances. Herd-level factors affecting reproductive performance include estrus detection efficiency, use of anestrus treatments, pharmacological ovulation synchronization, and bull management. These would also have accounted for some of the herd-year-season covariances if these factors interacted with variables associated with milk protein concentration in their effects on fertility. For some traits, the residual covariance constituted only a relatively small proportion of the covariances. For not pregnant by wk 21, not pregnant by end of breeding period, and calving interval, residual covariance (i.e., that not accounted for at genetic, permanent environmental, and herd-year-season levels) constituted only 14,13 , and $8 \%$ of the total covariances, respectively. In lactating dairy cows, the relationships between milk protein concentration and reproductive performance remained after adjusting for estimated breeding values for fertility (Morton et al., 2017). This may have been because substantial components of the relationship are nongenetic, but measurement errors in estimates of each cow's estimated breeding value for fertility may 
also have contributed to failure to fully account for genetic components of the relationships.

The positive phenotypic associations between milk protein concentration and reproductive performance traits are most likely to be due to factors affecting both milk protein concentration and reproductive performance. This relationship has been attributed to energy balance during early lactation (Yang et al., 2009; Madouasse et al., 2010). Negative energy balance has been associated with reduced reproductive performance (Canfield et al., 1990; Reist et al., 2003; Patton et al., 2007), and milk protein concentration in early lactation is higher in cows with less negative energy balance (Grieve et al., 1986; Garvin, 1999). González-Recio et al. (2016) examined the value of using energy balance predicted using conformation traits to improve the reliability of fertility breeding values in Australia and concluded there was limited predictive value. However, McParland et al. (2011) showed that energy balance could be predicted using midinfrared spectral data obtained from milk recording; this latter trait should be compared with milk protein concentration in multitrait genetic models to predict female fertility.

Associations between milk fat-to-protein ratio and energy balance (Grieve et al., 1986; Mäntysaari and Mäntysaari, 2010) are probably also due, in part, to the relationship between milk protein concentration and energy balance. However, factors other than energy balance during early lactation may also contribute to the phenotypic relationships between milk protein concentration and reproductive performance traits. Milk protein concentration is generally only weakly associated with extent of postpartum negative energy balance (Grieve et al., 1986). Increases in milk protein concentration after postpartum negative energy balance has ceased are relatively small, and marked negative energy balances induced by feed restriction during lactation result in only relatively small reductions in milk protein concentration (Gross et. al., 2011; Abdelatty et. al., 2017). Fahey et al. $(2008,2017)$ showed that the association is evident in nulliparous heifers, as primiparous animals with higher milk protein concentration in their first lactation had conceived earlier as nullipara (when they were not lactating and when negative energy balance would not be expected). Morton et al. (2016b) assessed the relationship using milk protein concentrations measured at various stages of lactation. Even though negative energy balance is most severe in the first $30 \mathrm{~d}$ of lactation (de Vries and Veerkamp, 2000), estimated associations for concentrations assessed in d 31 to 60 of lactation were stronger than for 0 to $30 \mathrm{~d}$, and milk protein concentration during the cow's breeding period was also positively associated with the subsequent daily hazard of conception. These findings indicate that factors other than energy balance during early lactation probably contribute to the phenotypic relationships between milk protein concentration and reproductive performance traits. Douglas et al. (2016) showed that cows with high milk protein concentration have plasma profiles of selected metabolites and hormones that indicate greater partitioning of nutrients to physiological processes other than milk synthesis at the benefit of body condition.

Bello et al. (2012) looked at the antagonism between fertility and milk yield at cow and herd level. In the current study, we separated the association into 4 different components. Associations between fertility traits and milk protein concentration were positive at all levels, and most correlations were closer to unity than absolute correlations with milk yield. This suggests that many strategies that increase milk protein concentration also increase fertility. This is also the reason for the strong phenotypic associations between fertility and milk protein concentration. In the case of milk yield, although selection for milk yield reduces fertility due to the unfavorable genetic correlations, as seen in the current study and other studies (e.g., Harris et al., 2005; Haile-Mariam et al., 2013; Berry et al., 2014), permanent environmental effects of cow may have positive or negative effects on both milk yield and fertility. Herd management factors also have an influence on both milk yield and time to first service (as reflected by submission by wk 3 and calving to first service interval).

Compared with the large InCalf study in Australia from 1996 to 1998 (Morton, 2004), the reproductive performance of cows in the current study was lower. In the 1996 to 1998 study, the mean calving interval (d), calving to first service interval (d), 6-wk pregnancy rate (\%), 3-wk submission rate (\%), and first-service conception rate (\%) were $372,77,55,68$, and 49 , respectively (Haile-Mariam et al., 2003b). The heritability estimates for fertility traits from the current study were low and comparable to estimates based on similar Australian data (e.g., Haile-Mariam et al., 2003b) and estimates from other countries (e.g., Berry et al., 2014). On the other hand, our heritability estimates for milk yield and milk protein concentration were lower than most previous reports (e.g., Haile-Mariam and Goddard, 2008) because they are actually intraherd heritabilities, where the phenotypic variance includes herd-year-season variance.

\section{CONCLUSIONS}

In conclusion, as the associations between milk protein concentration and fertility traits have substantial nongenetic components, research is required to iden- 
tify management strategies that use the relationship between milk protein concentration and reproductive performance. Further research into the use of milk protein concentration as an indicator trait in future breeding objectives for fertility should also be considered. Importantly, the benefits of these strong relationships can only be harnessed through joint use of both management strategies and genetic strategies.

\section{ACKNOWLEDGMENTS}

We gratefully acknowledge the assistance of veterinarians who supplied data for this study: Jakob Malmo (Maffra Veterinary Centre, Maffra, Victoria, Australia), Peter Younis and Dave Colson (The Vet Group, Timboon and Warrnambool, Victoria, Australia), Steve Jagoe (Warrnambool Veterinary Clinic, Warrnambool, Victoria, Australia), and Neil Leighton (Smithton Veterinary Services, Smithton, Tasmania, Australia), as well as DataGene (Melbourne, Australia) and Paul Koh, who supplied data from the DataGene database. Jennie Pryce and Mekonnen Haile-Mariam received funding from DairyBio a joint initiative of Agriculture Victoria (Melbourne, Australia) and Dairy Australia (Melbourne, Australia).

\section{REFERENCES}

Abdelatty, A. M., M. E. Iwaniuk, M. Garcia, K. M. Moyes, B. B. Teter, P. Delmonte, A. K. G. Kadegowda, M. A. Tony, F. F. Mohamad, and R. A. Erdman. 2017. Effect of short-term feed restriction on temporal changes in milk components and mammary lipogenic gene expression in mid-lactation Holstein dairy cows. J. Dairy Sci. 100:4000-4013.

ADHIS (Australian Dairy Herd Improvement Scheme). 2004. ABV Handbook Cows N Genes Workshop Manual. ADHIS, Melbourne, Australia.

Auldist, M. J., G. O'Brien, D. Cole, K. L. Macmillan, and C. Grainger. 2007. Effects of varying lactation length on milk production capacity of cows in pasture-based dairying systems. J. Dairy Sci. 90:3234-3241

Bello, N. M., J. S. Stevenson, and R. J. Tempelman. 2012. Milk production and reproductive performance: Modern interdisciplinary insights into an enduring axiom. J. Dairy Sci. 95:5461-5475.

Berry, D. P., E. Wall, and J. E. Pryce. 2014. Genetics and genomics of reproductive performance in dairy and beef cattle. Animal 8(Suppl. 1):105-121.

Brownlie, T. S., J. M. Morton, and S. McDougall. 2016. Accuracy of fetal age estimates using transrectal ultrasonography for predicting calving dates in dairy cows in seasonally calving herds in New Zealand. N. Z. Vet. J. 64:324-329.

Canfield, R. W., C. J. Sniffen, and W. R. Butler. 1990. Effects of excess degradable protein on postpartum reproduction and energy balance in dairy cattle. J. Dairy Sci. 73:2342-2349.

de Vries, M. J., and R. F. Veerkamp. 2000. Energy balance of dairy cattle in relation to milk production variables and fertility. J. Dairy Sci. 83:62-69.

Douglas, M. L., L. C. Marett, K. L. Macmillan, J. M. Morton, M. C. Hannah, A. D. Fisher, and M. J. Auldist. 2016. Associations of high and low milk protein concentrations with energy allocation, milk production, and concentrations of blood plasma metabolites and hormones in Holstein-Friesian cows. J. Dairy Sci. 99:1005710066.

Fahey, J., J. M. Morton, M. J. Auldist, and K. L. Macmillan. 2017. Associations between early lactation milk protein concentrations and the intervals to calving for Holstein cows of differing parity. Anim. Prod. Sci. 57:2100-2109.

Fahey, J., J. M. Morton, and K. L. Macmillan. 2008. Associations between milk protein concentrations and preceding reproductive performance in Holstein-Friesian heifers and cows in Australia. Proc. N.Z. Soc. Anim. Prod. 68:69-72.

Garvin. J. K. 1999. The effect of dietary protein degradability and genetics on the protein quality of milk for cheese manufacture. $\mathrm{PhD}$ thesis, Department of Animal Science, Faculty of Veterinary Science, University of Sydney, Sydney, Australia.

Gilmour A.R., B. J. Gogel, B. R. Cullis, and R. Thompson. 2009 ASReml User Guide Release 3.0. VSN International Ltd., Hemel Hempstead, UK.

González-Recio, O., M. Haile-Mariam, and J. E. Pryce. 2016. Improving the reliability of female fertility breeding values using type and milk yield traits that predict energy status in Australian Holstein cattle. J. Dairy Sci. 99:493-504.

Grieve, D. G., S. Korver, Y. S. Rijpkema, and G. Hof. 1986. Relationship between milk composition and some nutritional parameters in early lactation. Livest. Prod. Sci. 14:239-254.

Gross, J., H. A. van Dorland, R. M. Bruckmaier, and F. J. Schwarz. 2011. Performance and metabolic profile of dairy cows during a lactational and deliberately induced negative energy balance with subsequent realimentation. J. Dairy Sci. 94:1820-1830.

Haile-Mariam, M., P. J. Bowman, and J. E. Pryce. 2013. Genetic analyses of fertility and predictor traits in Holstein herds with low and high mean calving intervals and in Jersey herds. J. Dairy Sci. 96:655-667.

Haile-Mariam, M., and M. E. Goddard. 2008. Genetic and phenotypic parameters of lactations longer than 305 days (extended lactations). Animal 2:325-335.

Haile-Mariam, M., J. M. Morton, and M. E. Goddard. 2003a. Can milk protein percentage or yield serve as indicator of fertility (calving interval) in dairy cattle? Pages $72-76$ in Proc. Assoc. Adv Anim. Breed. Genetics. Vol. 15. AAABG, Melbourne, Australia.

Haile-Mariam, M., J. M. Morton, and M. E. Goddard. 2003b. Estimates of genetic parameters for fertility traits of Australian Holstein-Friesian cattle. Anim. Sci. 76:35-42.

Harris, B., J. E. Pryce, Z. Z. Xu, and W. A. Montgomerie. 2005. Fertility breeding values in New Zealand, the next generation. Interbull Bull. 2005:47-50.

Harris, B. L., and J. E. Pryce. 2004. Genetic and phenotypic relationships between milk protein percentage, reproductive performance and body condition score in New Zealand dairy cattle. Proc. N.Z. Soc. Anim. Prod. 64:127-131

Madouasse, A., J. N. Huxley, W. J. Browne, A. J. Bradley, I. L. Dryden, and M. J. Green. 2010. Use of individual cow milk recording data at the start of lactation to predict the calving to conception interval. J. Dairy Sci. 93:4677-4690.

Mäntysaari, P., and E. A. Mäntysaari. 2010. Predicting early lactation energy balance in primiparous Red Dairy Cattle using milk and body traits. Acta Agric. Scand. Anim. Sci. 60:79-87.

Matthews, B. J., and J. M. Morton. 2012. Accuracy of predicted calving dates in Holstein-Friesian dairy cows based on fetal ages estimated using manual rectal palpation. N. Z. Vet. J. 60:234-240.

McParland, S., G. Banos, E. Wall, M. P. Coffey, H. Soyeurt, R. F. Veerkamp, and D. P. Berry. 2011. The use of mid-infrared spectrometry to predict body energy status of Holstein cows. J. Dairy Sci. 94:3651-3661.

Morton, J. 2011. InCalf Fertility Data Project 2011, Dairy Australia, Melbourne, Victoria, Australia.

Morton, J. M. 2004. Determinants of reproductive performance of dairy cows in commercial herds in Australia. Ph D thesis. Faculty of Veterinary Science, University of Melbourne, Melbourne, Australia. Accessed Aug. 8, 2017. http://hdl.handle.net/11343/38864. 
Morton, J. M., M. J. Auldist, M. L. Douglas, and K. L. Macmillan. 2016a. Associations between milk protein concentration, milk yield, and reproductive performance in dairy cows. J. Dairy Sci. 99:10033-10043.

Morton, J. M., M. J. Auldist, M. L. Douglas, and K. L. Macmillan. 2016b. Associations between milk protein concentration at various stages of lactation and reproductive performance in dairy cows. J. Dairy Sci. 99:10044-10056.

Morton, J. M., M. J. Auldist, M. L. Douglas, and K. L. Macmillan. 2017. Milk protein concentration, estimated breeding value for fertility, and reproductive performance in lactating dairy cows. J. Dairy Sci. 100:5850-5862.

Olori, V. E., T. H. E. Meuwissen, and R. F. Veerkamp. 2002. Calving interval and survival breeding values as measure of cow fertility in a pasture-based production system with seasonal calving. J. Dairy Sci. 85:689-696.

Opsomer, G., Y. T. Grohn, J. Hertl, M. Coryn, H. Deluyker, and A. de Kriuf. 2000. Risk factors for post-partum ovarian dysfunction in high producing dairy cows in Belgium: A field study. Theriogenology 53:841-857.
Patton, J., D. A. Kenny, S. McNamara, J. F. Mee, F. P. O'Mara, M. G. Diskin, and J. J. Murphy. 2007. Relationships among milk production, energy balance, plasma analytes, and reproduction in Holstein-Friesian cows. J. Dairy Sci. 90:649-658.

Rajala-Schultz, P. J., and Y. T. Grohn. 1999. Culling of dairy cows. Part III. Effects of diseases, pregnancy status and milk yield on culling in Finnish Ayrshire cows. Prev. Vet. Med. 41:295-309.

Reist, M., D. K. Erdin, D. von Euw, K. M. Tschumperlin, H. Leuenberger, H. M. Hammon, C. Morel, C. Philipona, Y. Zbinden, N Kunzi, and J. W. Blum. 2003. Postpartum reproductive function: Association with energy, metabolic and endocrine status in high yielding dairy cows. Theriogenology 59:1707-1723.

Sun, C., P. Madsen, M. S. Lund, Y. Zhang, U. S. Nielsen, and G. Su. 2010. Improvement in genetic evaluation of female fertility in dairy cattle using multiple-trait models including milk production traits. J. Anim. Sci. 88:871-878.

Yang, L., N. Lopez-Villalobos, D. P. Berry, and T. Parkinson. 2009. Phenotypic relationships between milk protein percentage and reproductive performance in three strains of Holstein Friesian cows in Ireland. Proc. N.Z. Soc. Anim. Prod. 70:29-32. 